\title{
Sobretudo as vozes, de Silvina Rodrigues Lopes
}

\author{
Mauricio Salles Vasconcelos \\ Universidade de São Paulo
}

m "A poesia, memória excessiva", um dos ensaios de Literatura, defesa do atrito, Silvina Rodrigues Lopes sublinha, no estudo de alguns versos de Joaquim Manuel Magalhães, a emergência do poema como realidade ativa, reveladora, contraposta ao processo de recordação atribuível a um evento passado. "[...] o poema testemunha a verdade que ele é, não uma verdade que relata" (LOPES, 2003: 61).

Ao articular a dimensão do acontecimento em sua análise, sintonizada com a circulação de um conceito que atravessa a esfera da filosofia e se propaga em vários campos das ciências humanas e até mesmo para fora desse âmbito, a ensaísta deixa, também, inscrito o sentido de partilha - "partilha de presenças" (p. 61). Fundamental à existência de algo compreensível como escrita de poesia, tal nominação lança um rastro de relações muito próximo de Foucault, quando o filósofo se concentra na pesquisa do estado atual dos signos que materializam a criação de um texto reconhecível como literatura, ao observar o caráter particular de reconfiguração de um saber dispersado e reunido sob a dinâmica das fronteiras, de um movimento nunca concludente do escrito em matéria auto-referente, nem em simples documento cultural da enciclopédia/biblioteca. E, no caso da poesia, lê-se partilha como corte e contágio entre planos, assim como distribuição do ritmo, da visualidade e do conceito (próprios à chamada forma poética, resumidos na tríade melopéia/fanopéia/ logopéia, composta por Pound) a contar da heterogeneidade da linguagem em vizinhanças disciplinares e discursivas as mais diversas.

O fato de Silvina Lopes publicar um livro de poesia após a consolidação de uma ensaística interferente, essencial à literatura portuguesa de hoje, poderia lançá-lo na órbita dos escritos reconhecíveis como de poeta-professor-teóri- 
co de literatura. Mas há algo que se move para além da lógica da identidade e da iteração. Sobretudo quando se nota o substrato de uma diçãa, montada sobre variáveis e derivações da voz.

Sobretudo as vozes vai se mostrando em sua leitura como deliberado, bem construído, projeto de um livro de poesia - a autora tem sua foto apropriada, colorizada, em novos traços gráficos na capa de um pequeno volume pregnante, possante. Trata-se aqui de uma incursão - a potência auto-enunciadora da linguagem se nutre, igualmente, da passagem pelo corpus do poético na atualidade, daquela poeticidade do mundo abordada por Kostas Axelos em seus estudos sobre o pensamento planetário.

O mundo é sempre intermédio. Partir, é a cintilação. Estendo os braços, a noite começa a desenrolar-se. (p. 12)

Toda uma rede mitopoética, erguida pelos motivos da deambulação, da itinerância, vai se compondo em conexão e coexistência com os multidimensionamentos do mundo atual, aberto às constelações de sentido formadas entre globalização e planeta, tecnologia e subjetividade, geopolítica e nomadismo, História e devir. É o que se dá a ler em versos que se espraiam e se compactam numa tessitura autônoma e, a um só tempo, convergente com o que se conhece e pensa a partir da poesia. Acontecimento do conbecimento.

...O antes e o depois, as ruas e as montanhas sobrepõem-se. Mas é preciso escolher. É sempre preciso escolher entre o erro e a vida que se confunde com o papel de parede. Partir vem de dentro do inconciliável. É outra coisa. Mais e menos do que o perigo do erro - a errância, a solidão que esboroa a fotografia. (p. 5-6)

Nada é linear, nem unilateral, no trabalho poético inaugurado por Silvina Lopes em Sobretudo as vozes. Nada soa como simples referendamento às tradições e às rupturas das modernidades ao longo do século XX. Não há como apreender os pontos cruzados das vozes aqui presentes - menos em culto do que em partilha -, dentro de uma generalização frágil e indeterminadamente concebida como "pós-moderna". Mostra-se inviável simplificar as ligações aqui produzidas, ainda que repercutam as passagens por topoi e imagens relacionáveis 
com Herberto Helder (tema de $A$ inocência do devir, um dos seus muitos livros de ensaio), Ramos Rosa, Sophia, Fiama, Joaquim M. Magalhães (em termos do sempre imponente "lirismo português"), para não se falar de elos menos perceptíveis com uma vertente de celebração e espacialização da experiência conjunta de poema e poeta, possível de se traçar de Hölderlin a Jabès.

O que mais impressiona no livro de poesia de Silvina Rodrigues Lopes é o itinerário do longo poema que aí se engendra ou dos muitos núcleos poemáticos concebidos em prosa dentro de um continuum, tomados, contudo, pelas variações de linha e vOz - dos chamamentos que constituem um princípio de ritmo - "Nada, senão ter ouvido chamar. Ter chamado" (p. 5) -, até se instalar um movimento que alia a relação som/imagem a um incurso travado em torno do erro e da errância, da dispersão e do acolhimento. Não à toa, figura a imagem do hóspede depois do diálogo com o desconbecido (p. 13), como experiência extensiva a uma leitura múltipla de Jabès (autor de O livro da hospitalidade), Derrida, Blanchot e Lévinas. Porém, Sobretudo as vožes testemunha seu próprio, peculiar enfrentamento - autonarratividade e aprendizagem no diverso, no disperso. Partilha de conhecimento e criação.

Pediu um presente de hospitalidade que fosse dado testemunho. Da cólera não, nem da vingança, que eram ruidosas e apertavam o horizonte.

Testemunho do que volta e é esperado. Sem abdicações, jogado em amor do mundo, de nada ser idêntico ou circular. (p. 74)

O livro aprende - no andamento de um transcurso, ao alcance de uma contra-moral sustentada pelo esquecimento e pela desaparição. Por uma via estreita, o poema encontra seu desenlace no momento mesmo em que sua continuidade se repõe, reconfigurando-se em outra margem. Retoma o princípio: chamado e voz multiplicada. Paradoxo do poema contínuo helderiano redefinido em um novo momento, por uma diferente partilha da cultura.

No correr de uma linha a outra de Sobretudo as vožes, traça-se o desenho de uma intervenção na literatura que se faz agora (a atuação de Silvina à frente da editora Vendaval mereceria uma análise à parte). Na amplitude de relações 
do escrito e do poeta, compreendido como agente, produtor cultural (não simplesmente autor), é que todo um trabalho crítico e estético se situa. Nele se fortalece o sentido sempre movente das constelações/conjunções desbravadas por um crítico/narrador como W. Benjamin. A atividade teórica da ensaísta de Literatura, defesa do atrito se comprova como favorecedora tanto do amadurecimento quanto da abertura que o poema de estréia apresenta.

Na cena contemporânea dos muitos debates envolvendo os impasses da teoria após as desconstruções e os culturalismos timbrados pela posterioridade de uma época, desponta na produção de Silvina Rodrigues Lopes uma outra postura intelectual na afirmação radical do poético, tendo como base um amplo lastro filosófico e teórico, mas, também, uma escolha - que conduz a uma partilha dos signos em vigor na atualidade - por figuras de risco, de desabrigo, compreensíveis como índices de uma aposta aberta em um mundo em deriva, em devir. Em extensão, sua poesia se constrói na contracorrente das imagens, dos rostos de poeta coroados em "sua" linguagem, assimiláveis como inserção em um lugar já dado culturalmente. Tudo, pelo contrário, aqui se orienta, sem nenhuma definição prévia, a partir do momento em que o poema "é escrito e ele não existe antes disso" (LOPES, 2003: 67).

...os gestos

recíprocos e verdadeiros estendem-se

na superfície celeste, abraçam constelações, queimam-se no brilho de uma infância iminente. (LOPES, 2004: 32)

Como diz Silvina Lopes no ensaio citado, o poema é considerado não apenas como conseqüência do lugar, mas, especialmente, como "causa do lugar que ele é" (ibid.). Nessa dimensão, o elo entre pensamento e poesia só faz potencializar a atividade atualizadora e plural do poeta. Por outro lado, a poesia recorta, no campo do saber atual, um universo particular e crescente de abordagens filosóficas, bastante conhecido por ela, Silvina. Há um trânsito intermitente e intensificado entre diferentes áreas do conhecimento, que a escrita dessa autora faz convergir para a poesia e o poeta como pólos renovadores de discussões ocorridas em outros planos (técnicos, científicos, teóricos).

A poética de Sobretudo as vozes atua como se elaborasse, linha a linha, um 
mapa de incidências da escrita, um corpus (no sentido topográfico conceituado por J-L Nancy) direcionado em mais de um sentido, em um alinhamento polarizador, magnetizador - "Sobretudo as vozes. O que passa em campos e não é comum. Magnetiza, desvia" (p.72) -, ainda que intencionalmente tortuoso, sinuoso. Uma escrita mais próxima da busca do que da formatação up-todate contida em certa noção de contemporâneo. Tornam-se viscerais os atos de deambulação/movimento/partida presentes, de modos diferentes, em Rousseau, Rimbaud, Walser, Ana C., Lyn Hejinian, pelo veio do fragmento, da anotação desgarrada de gênero e de livro, de uma certa formulação aforismática (com toda a sua disjunção e não-filiação, aberta que é ao instante). Atitude que se alinha a uma literatura do não-fundamento, portátil (do como a concebe Villa-Matas), potencialmente preparada para adotar a criação como experiência. Põe-se à prova do acontecimento, algo indissociável de um verdadeiramente inaugural primeiro livro de poesia.

\section{Referências Bibliográficas}

LOPES, Silvina Rodrigues. Sobretudo as vožes. Lisboa: Vendaval, 2004. . A poesia, memória excessiva, marcas do desespero, defesa do atrito. In: . Literatura, defesa do atrito. Lisboa: Vendaval, 2003. 